\title{
Research
}

\section{Ecosystem and Social Construction: an Interdisciplinary Case Study of the Shurkul Lake Landscape in Khorezm, Uzbekistan.}

\author{
$\underline{\text { Lisa Oberkircher }}^{1}, \underline{\text { Margaret Shanafield }}^{2}$, Bashorat Ismailova $^{3}$, and Laurel Saito ${ }^{4}$
}

\begin{abstract}
Transformation of the Khorezm region of Uzbekistan from forested to agricultural landscapes resulted in the formation of hundreds of lakes, the dynamics of which are largely controlled by inputs from irrigation runoff waters. The importance of the ecological and socio-cultural dimensions of one of these lakes, Shurkul, is discussed in order to understand the connection between humans and their environment. Landscape is used as a boundary concept, and we combine quantitative methods of the natural sciences with qualitative methods of the social sciences to assess these dimensions of the lake landscape. In the ecological dimension, Shurkul performs a wide range of ecosystem services from wildlife habitat and foodweb support to the provision of fish, fodder, building material and grazing ground. In the socio-cultural dimension, the lake is part of local ecological knowledge, functions as a prestige object and recreational site, and is rooted in religious beliefs of the population as a symbol of God's benevolence. The Shurkul landscape may thus create a feeling of environmental connectedness and the desire to act in favor of the natural environment, which could be made use of in environmental education programs.
\end{abstract}

Key Words: connectedness to nature; Central Asia; lake ecosystem; landscape; local ecological knowledge; perception; Shurkul lake; social construction

\section{INTRODUCTION}

Lakes and their landscapes provide a variety of ecosystem services, especially in terms of water resource availability and supporting services such as nutrient cycling and photosynthesis (Feld et al. 2009). In a recent assessment of freshwater ecosystems in Europe, Harrison et al. (2010) noted that current cultural services of European lakes were minimal, although lakes have inspired and attracted humans for generations. However, they found that European agricultural landscapes have played important roles in creating a sense of place and cultural heritage values because of the work and sustenance agriculture has provided over time. In the study presented here, connections between the ecological and social dimensions of a small lake surrounded by agriculture in Uzbekistan were examined to investigate the roles such small lakes play in peoples' lives, and how the value of the lakes can aid in efforts to promote environmental conservation.

During the twentieth century, many irrigable lands in Uzbekistan were transformed from a forested landscape to an agricultural landscape. In the Khorezm region in Uzbekistan, a Tugai forest oasis situated at the Amu Darya River between the Kyzylkum and Karakum deserts became an agricultural landscape. This landscape was crisscrossed by irrigation canals that supported a cotton monoculture to supply textile factories under the Soviet Union. The landscape transformation affected the Aral Sea, which shrank rapidly in response to reduced inflows from the Amu Darya River (Micklin 2007). In addition, it affected the ecology of the Khorezm region, in part due to a raised groundwater table, increased soil salinity, and environmental pollution resulting from extensive fertilizer and pesticide application. Hundreds of new lakes, or kuls in Uzbek, formed as irrigation runoff water filled natural depressions in the landscape. Although many of the lakes may have existed before construction of large-scale irrigation and drainage canals in the region, the depth, flow regime, salinity, and nutrient levels in these lakes are now largely controlled by inputs from irrigation runoff waters (Scott et al. 2011). Remote sensing classification of water bodies $>1$ ha with Landsat-7 ETM+ data detected 421 lakes with a total area of 6076.3 ha in Khorezm, excluding the districts Pitnyak, Xasarasp and part of Bogot (Kaiser 2005).

A case study of one of these lakes, Shurkul, located in the southwest of Khorezm (Figure 1) will be presented. Preliminary age dating for Shurkul based on Cesium-137 and $\mathrm{Pb}-210$ indicates that lake sediments are on the order of one hundred years old (M. Rosen, 2010, personal communication). During the drought of 2008, residents of settlements surrounding Shurkul suffered from reduced irrigation and domestic water supplies. To overcome the problems caused by water scarcity, scientists from a German-Uzbek research project met with staff of the water user association and local farmers to discuss improvement strategies. The scientists had expected that securing drinking water and irrigation water availability would be important topics to the community. However, many of the local stakeholders also voiced their concern for the drastically reduced water level in Shurkul, and wanted to take measures to restore it to its pre-drought state. At the same time, a study of the aquatic food web and water quality in Shurkul was being conducted. This combination of factors provided the impetus for an interdisciplinary analysis

\footnotetext{
${ }^{1}$ Institute of Landscape Ecology, WWU Münster, ${ }^{2}$ National Centre for Groundwater Resarch and Training, Flinders University, ${ }^{3}$ ZEF/UNESCO Khorezm Project, ${ }^{4}$ University of Nevada Reno
} 
of the various dimensions of the Shurkul landscape. The lake provides both ecosystem services and has an important sociocultural dimension in local villages, and it was apparent that the latter plays a significant role in the environmental perceptions of the rural population. The research question of this article's study was formulated as follows: What functions does the Shurkul landscape fulfill in the lives of the local residents, both as a service-providing ecosystem and as social construction?

Fig. 1. Map of the study area showing the location of Shurkul in the Khorezm province (source: GIS-lab of the ZEF-UNESCO project).

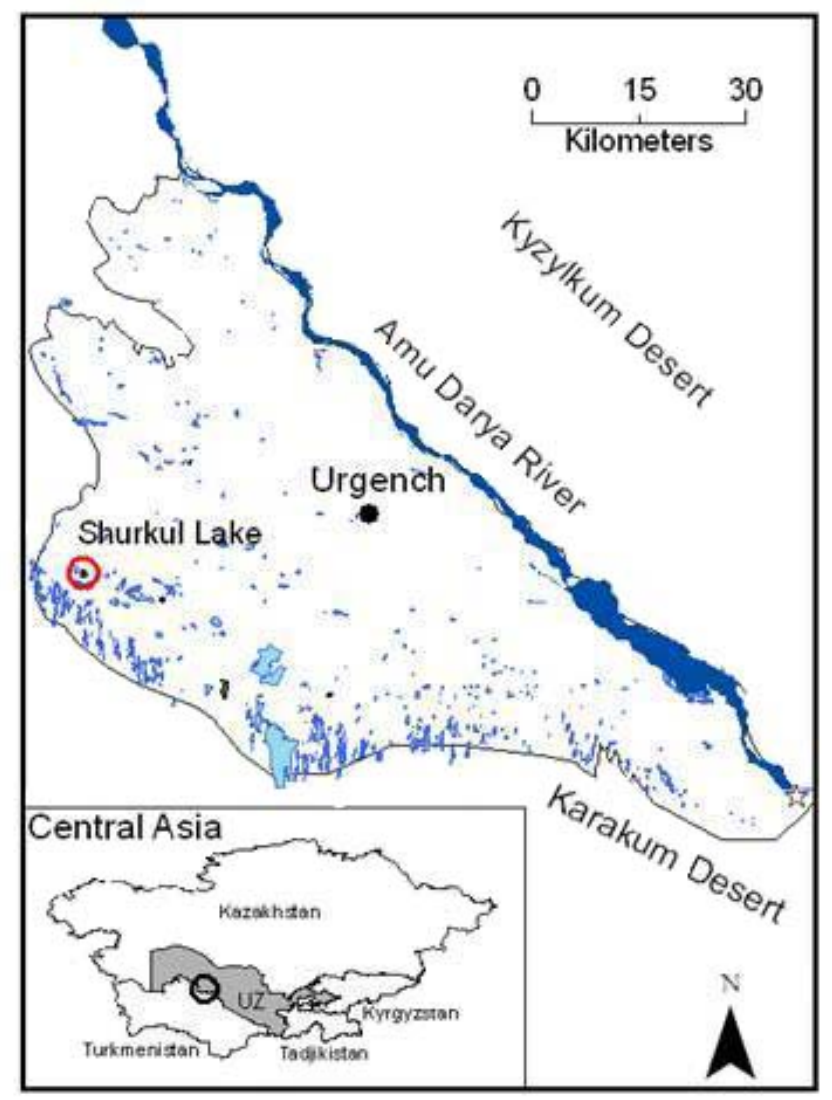

\section{CONCEPTUAL FRAMEWORK}

In this study we combine ecological surveys with qualitative social science research as an interdisciplinary approach to examine the role of small lakes in Khorezm, using Shurkul as a case study. This fusion of natural and social science methods was chosen to gain a better understanding of the connection between humans and their environment, because a lake is not only a limnological system that provides ecosystem services, but it is also socially constructed by the rural population in the villages surrounding the lake in the sense of Berger and
Luckmann (1966). To develop a common conceptual understanding from the perspective of the different disciplines involved, we use the boundary-crossing framework for interdisciplinarity as suggested by Mollinga (2010). Boundary concepts are defined as words that function as concepts in different disciplines or perspectives, refer to the same object, phenomenon, process or quality of these, but carry sometimes very different meanings in those different disciplines or perspectives. In other words, they are different abstractions from the same "thing".

Here we use "landscape" as our boundary concept. The term landscape has Germanic roots and appeared in the early Middle Ages, first as a settlement space with specific groups of people having norms and codes of conduct, as opposed to forests or other areas not subject to human developments (Kaufmann 2005). In the $15^{\text {th }}$ and $16^{\text {th }}$ centuries, this concept acquired an aesthetic meaning as a term used in the arts in the sense of landscape painting, and thus became an image in addition to a material phenomenon. This understanding of an image facilitated a conceptualization of landscape in the sense of an aesthetic perception process and the concept of landscape thus entered philosophical discourses. From the $19^{\text {th }}$ century on, landscape appears in the academic literature of the disciplines of history and geography. While landscape forms a central concept (Kaufmann 2005) of the latter, the use of the term has been extremely broad in geography and in the newer discipline of landscape ecology, extending from a simple understanding of a region to an image, system of interaction, ecosystem, or even a mere metaphor for phenomena of any kind (Hard and Gliedner 1977).

Buchecker (1999), based on Werlen (1986), distinguishes two main approaches to the concept of landscape: (1) the positivist view of landscape as objectively tangible, and (2) the phenomenological view of landscape as a social construction. While the field of geography is often criticized for not offering a uniformly applicable concept of landscape, the diversity of understandings may make landscape particularly useful as a boundary concept. In accordance with Löwy (1992), who stresses that interdisciplinarity is sometimes better served by less precisely defined, but instead flexible concepts, we define landscape here as a concept with two different dimensions: an ecological dimension, for example, as understood by Forman (1981), and a socio-cultural dimension that includes both aesthetic and symbolic social construction processes, such as cultural landscapes of the UNESCO World Heritage Program.

For the empirical research of Shurkul we thus conceptualize our object of study as a lake landscape. On the one hand, this landscape consists of its material setting, i.e., the lake, its biophysical surroundings with vegetation and other organisms, and the two villages Ortayop and Uyghur as settlements near the lake (Figure 2 and Table 1). This material 
Fig. 2. Shurkul and the surrounding villages Uyghur and Ortayop (source: Google Earth).

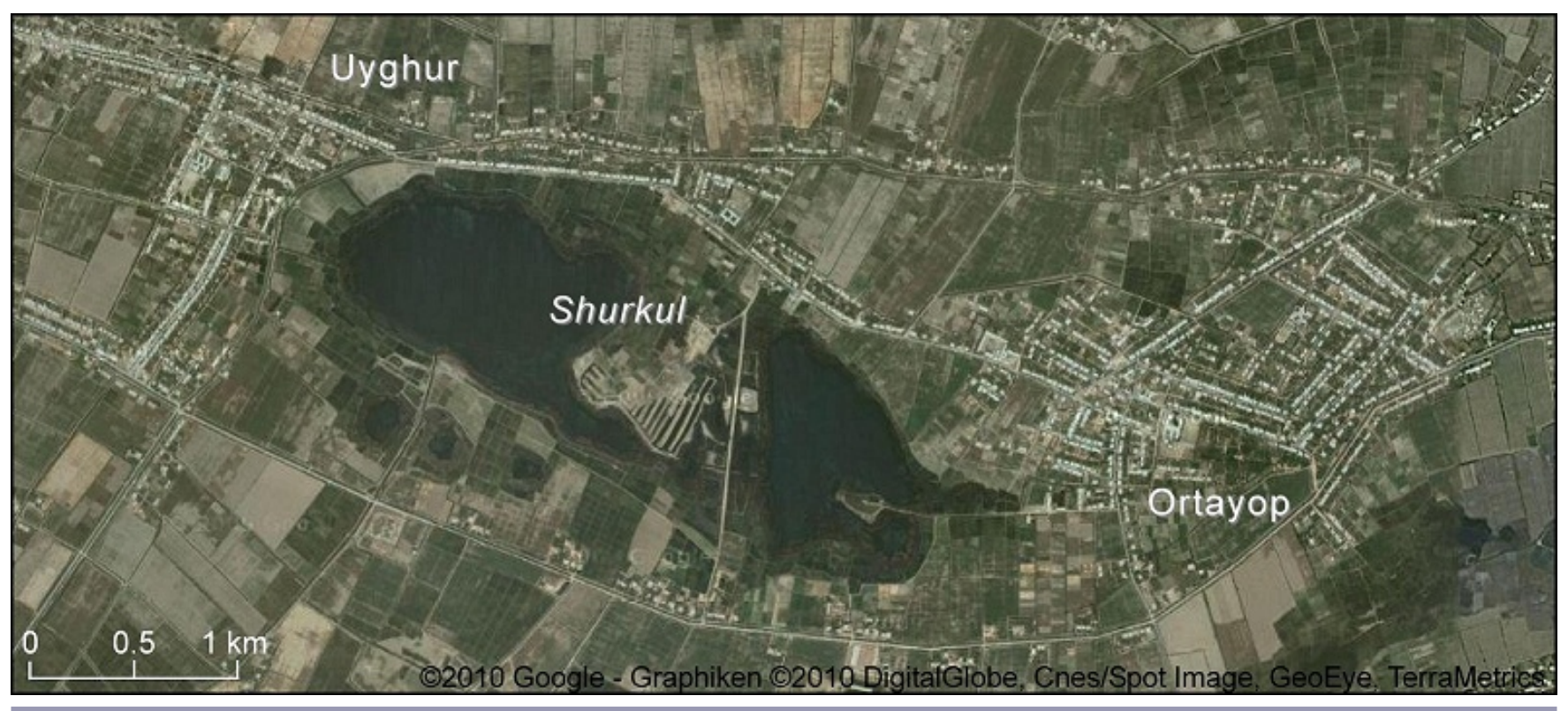

Table 1. Characteristics of the study site

Hydrol- Precipitation approx. $90 \mathrm{~mm}$, annual average potential ogy evapotranspiration approx. 1,500 mm (Conrad 2006)

Soils Medium and heavy loam soil textures prevailing, clayey light loam and sandy loam soils less widespread, approx. $50 \%$ of soils moderately or strongly saline (Ibrakhimov et al. 2007)

Crops Main crops in summer are cotton and rice, in winter, spring wheat; all crops irrigated either with basin or furrow irrigation

Villages Ortayop and Uyghur with approx. 5900 and 5000 residents, respectively. The majority of the population involved in agriculture either as private farmers, peasants, workers on private farms, or a combination of the latter two.

landscape is an ecosystem that can be studied with quantitative methods of the natural sciences, and it can provide multiple ecosystem services, including those defined by the Millennium Ecosystem Assessment (2005) as provisioning (e.g., food in the form of fish, water for irrigation and fish production), regulating (e.g., water regulation and purification, and climate regulation), and supporting services (e.g., nutrient cycling, soil formation, and primary production). On the other hand, the landscape also provides cultural ecosystem services and consists of the social constructions by the population in the two villages and all cultural and symbolic systems that prevail in the space occupied by material elements of the landscape. These processes of social construction are studied with qualitative social science methods.

\section{METHODS}

\section{Natural science methods}

The regulating ecosystem service of water purification and supporting services of nutrient cycling and primary production were investigated between June 2006 and December 2008 with surveys of physical and chemical water quality and food web components. Physical water quality parameters (dissolved oxygen concentration, salinity, and temperature) were measured monthly in a vertical profile at increments of $0.5 \mathrm{~m}$ using a hand-held sonde (YSI, Yellow Springs, USA). A grab sample was collected at a depth of $0.3 \mathrm{~m}$ at the center of the lake and tested immediately for $\mathrm{pH}$ using a hand-held meter (Consort, Turnhout, Belgium). Water samples were immediately filtered upon return from the field and kept frozen until nitrogen and phosphorus constituents were determined at the Hydrometeorological Research Institute (NIGMI) in Tashkent, Uzbekistan using photometric methods. Seasonal bioassays were performed in the lake in 2007 and 2008 to examine phytoplankton production with nitrogen and phosphorus additions. Food web samples, including zooplankton, macroinvertebrates, and fish, were collected twice per year during relatively low and high lake levels. Lake 
sediments were collected in June 2007, and a lake core sample was collected in July 2008. These samples and fish tissue samples from three fish collected at Shurkul were analyzed for DDT and lindane $(\mathrm{HCH})$ concentrations at NIGMI.

\section{Social science methods}

The importance of ecosystem services for local residents as well as further socio-cultural functions of the Shurkul landscape were studied with qualitative social science methods and data collection in the form of unstructured interviews during two field research phases from July to September 2008 and November 2009 to January 2010. Unstructured interviews rather than fixed questions were chosen to allow the interviewees to talk freely about the lake instead of being limited to the understandings of the researchers. The interview process began with general questions about activities around the lake or conversations about the lake view. The interviewee was then asked about his/her individual opinions or stories about the lake with spontaneous follow-up questions. The interviews were conducted during transect walks through the two villages Ortayop and Uyghur, and the selection of interviewees was random, meaning all villagers who were present and willing to talk were included. The duration of the interviews ranged from the time it took to exchange a few sentences while passing someone to conversations of about one hour. The interviewees included male and female local residents of different age groups. Particularly with older people, interviews included oral history accounts of the characteristics of the lake landscape in the past as well as of memories of their own experiences and past activities in relation to the lake. Atlas.ti software (Scientific Software Development, Berlin) was used to code and analyze interview data.

\section{RESULTS AND DISCUSSION}

\section{The ecosystem and its services}

Although the surface area of most Khorezm lakes is small, during the agricultural growing season the lakes are connected to one another and to the Amu Darya River with water entering the lakes from irrigation drainage canals and direct runoff from surrounding fields. Approximately $41 \%$ of the land within 500 $m$ of Shurkul was irrigated for the production of cotton, wheat, and other crops during the 2004 growing season (Conrad et al. 2007). As with other lakes in Khorezm that are mostly regulated by irrigation water runoff and evaporation with lesser contribution from groundwater (Scott et al. 2011), Shurkul receives surface water input from at least one drainage collector, as well as seasonal direct runoff from adjacent fields. Khorezm soils are generally of low fertility (Martius et al. 2004), which typically results in the heavy application of fertilizer. Studies in Uzbekistan found only $40 \%$ of the applied nitrogen was utilized by crops, leaving much of the applied fertilizer as excess that is either lost during direct runoff from fields, leaked to groundwater, volatilized to the atmosphere, or immobilized in topsoil (Khadjiyev and Bairov 1992, Ibrakhimov et al. 2007). During the study period 2006-2008, measured nitrogen concentrations in Shurkul were low, and were dominated by ammonium, which peaked in December to early spring at over $2 \mathrm{mg} / \mathrm{L}$, similar to many other lakes in the region. This seasonal pattern in nitrogen concentrations was also observed in the Amu Darya River during samplings conducted in 2006-2007 (Shanafield et al. 2010). Phosphorus levels were very low throughout most of the study period, with total phosphorus always below $0.4 \mathrm{mg} / \mathrm{L}$. The seasonal bioassays indicated that the lake was co-limited, with increased production when both nitrogen and phosphorus were added to lake water. Based on common trends observed in Shurkul and other lakes in the region, as well as observed Amu Darya River concentrations, Shanafield et al. (2010) concluded that nitrogen levels in the lakes are more reflective of concentrations entering the system from upstream than of fertilizer use on fields directly surrounding the lake. Because fertilizer application is state regulated for cotton and wheat, which are the main crops grown in the vicinity of the lake, it is unknown why runoff from local agricultural use does not have a greater impact on lake nutrient concentrations. It is possible that much of the local excess fertilizer is either volatilized (Scheer et al. 2008) or immobilized in topsoil (Kienzler 2010).

Most of the lakes in Khorezm are shallow, with an average depth of 1-2 $\mathrm{m}$. Therefore, they experience large seasonal shifts in water temperature. A maximum depth of approximately $3 \mathrm{~m}$ was measured during high water levels in Shurkul. Seasonal water temperatures ranged between 2 and $30^{\circ} \mathrm{C}$ during the study period, with $\mathrm{pH}$ values of 7.5 to 8.1 and dissolved oxygen concentrations generally inversely correlated with water temperature. Salinity in the lake was moderate at $2 \mathrm{~g} / \mathrm{L}$ during 2006 and 2007, but increased threefold to almost $6 \mathrm{~g} / \mathrm{L}$ in September and October 2008 (2008 was a drought year, and the lake reportedly had very little water in July and August 2008). Despite reported past heavy application of pesticides such as DDT, only very low levels of such pollutants were measured in the lake water column (Nishonov et al. 2009), sediments, lake core samples, and fish tissues. Ongoing microbial experiments are investigating the ability of lake sediments to break down DDT to explain the low pesticide concentrations.

During aquatic food web samplings, several species of rotifer, cladocera, and copepod zooplankton were observed, as well as predatory macroinvertebrates such as dragonflies (Odonata anisoptera)/ damselflies (Odonata zygoptera) and beetles (Dystiscidae), and fish such as snakehead (Channa argus warpachowskii (Berg.)), amur goby (Rhinogobius bruneus), common carp (Cyprinus carpio L.) and goldfish (Carassius carassius (Limne) or Carassius auratys gibelio (Block)). The observed dense patches of submersed macrophytes may provide habitat and support collected snail populations. 
Shurkul's physical water quality conditions thus support this variety of flora and fauna. On several occasions, fishing nets were observed in the lake, and the importance of the food web for local fish consumption was confirmed by interview statements such as "there are many people near the lake who fish and sell fish".

The nutrient-rich inflow waters that enter the lake support phytoplankton and submersed macrophyte growth that provide food for zooplankton and macroinvertebrate larvae, and spawning habitat and predation protection for various fish species. In addition, aquatic macroinvertebrates on which the fish feed, such as dragonfly and damselfly larvae, can find necessary aquatic breeding grounds in the lake. Other invertebrates such as shrimp migrate into the lake from the Amu Darya River (Kamilov and Urchinov 1995). The reeds surrounding the shores of Shurkul and similar lakes also provide habitat for aquatic species and are harvested by villagers for domestic needs. The role of Shurkul within the broader ecosystem has not been studied, but it may also provide habitat and a food source for migrating birds and larger mammals.

Under 2004 conditions, fish production was estimated to be $>3$ times more profitable than cotton production and almost $30 \%$ more profitable than wheat on the same land. If fish production were optimized for profitability, income from fish production could be increased $>7$ times over current estimates, making it more profitable than even rice (Abdoollaev 2005). At the tail end of the irrigation system, where Shurkul is located, making profits from agriculture is often difficult due to water scarcity and infertile soils and because of the distance from the provincial capital and other commercial centers, alternative sources of income are scarce. Theoretically, commercial fishing would hence be an attractive occupation for residents. To date, however, no farmer or enterprise has leased Shurkul from the state for private, commercial use. An interview with local authorities suggests that there has been little interest in leasing the lake because potential candidates seem discouraged by the responsibilities that come with a lease contract. The state is the official proprietor of all land including lakes and the land surrounding them, and leasing the lake from the state would include responsibilities such as the rational use of the lake, adequate management of its fish stocks, provision of information on its use to state authorities, compliance with nature protection legislation, and payment of rent/tax. If these duties are not fulfilled, a leaseholder can be fined and the lake lease can be taken away from him/her. A leaseholder of a lake cannot sell or sublease the whole lease or parts of it. He/she has the right to access, use and manage lake resources, but not to grant these rights to others because there is no exclusion or alienation rights in the sense of Ostrom and Schlager (1996) (RoU 2004a, RoU 2004b, RoU 1998). In addition, the lake's location at the tail end of the irrigation network and the risk of water scarcity may make it an unattractive lease.
Based on interview data, the ecosystem services most relevant to the local population are the ones defined by the Millennium Ecosystem Assessment (2005) as provisioning (e.g., food in the form of fish). However, regulating services were also mentioned, particularly in the context of weather phenomena. Currently, the lake is considered common property of the inhabitants of the closest village of Ortayop. All people are allowed to use the lake resources and many commonly do so by fishing, grazing cattle, and using the vegetation as fodder and building material. The ecosystem services that the lake provides are thus part of the local residents' subsistence system. As commented by one interviewee:

It is better to have lakes because of livestock and
fisheries. If there is no lake, drought occurs. There
are also people who depend on the lake [such as]
people who fish and sell fish. Also plants are sold
[by some people]. If children eat fish they grow
healthy.

Many people interviewed said that the 2008 drought had affected fishing and harvesting of vegetation negatively. Comments included: "Before there was a lot of fish. Now as water decreased there is less fish" and "last year as there was no water, the plants disappeared. This year, as there is water now, it improved a bit".

While Shurkul is not managed commercially at present, it may have potential for aquaculture. Exact numbers are not available for Shurkul specifically, but aquaculture in general has been identified as potentially profitable in Khorezm given the availability of cheap, local inputs such as fish feed (Kurambaeva 2008), and much of the Khorezm province is suitable for aquaculture based on economic and ecological considerations (Kranz 2005). Historically, fish consumption in Uzbekistan in 1991 was 12 times higher than in 2004, in part due to the loss of the fisheries of the Aral Sea region (Wecker et al. 2007, Food and Agriculture Organization 2009).

\section{The social construction}

Element of local ecological knowledge

Khorezm has a continental arid climate. Strong seasonal temperature variations with very low temperatures in winter and high temperatures in summer influence the agricultural cycle as well as the everyday practices of the rural population. Local water availability is less connected to weather events than to irrigation canal and groundwater levels. The latter contributes significantly to crop development (Forkutsa 2006) and works as a short-term buffer in times of water scarcity, although water levels do drop during extensive dry periods. Groundwater is an important water source for domestic uses such as drinking, cooking, and other household chores.

Often, water supply through the canal system is unreliable in tertiary canals such as the ones supplying the fields 
surrounding Shurkul, and changes in lake conditions represent an element of local ecological knowledge. Local ecological knowledge is here defined in the sense of Olsson and Folke (2001) as the knowledge of a particular group of people about local ecosystems. For example, in times of water scarcity, people regard the lake water level as an indicator of available groundwater supply. A major drought season occurred in Khorezm in 2008. By August 2008, most wells down to 4 or $5 \mathrm{~m}$ had dried out (Oberkircher 2011) and Shurkul had reduced in size significantly. The desiccation of the lake alarmed people, since it reflected the low water availability in the hydrologic system. In addition, the state of the lake was mentioned as a mirror and causal factor for the general health of the environment, both in the drought of 2008 , as well as the water abundant 2009:

Lakes are important for the ecology and for the air. In America and England they have made artificial lakes for the ecology. This shows how important lakes are. or The lake is important. With a lake, plants will grow, there will be fish and water plants. Its importance for the ecology is great.

The lake is also observed for weather predictions. One interviewee commented, for example, that "if the water of the lake is dark, it will rain. If it is brown or of soil color, then there will be strong wind. It will come within two hours." Thus, the lake is regarded as one element of an interconnected ecological system.

Local prestige object

In many other parts of Uzbekistan, the Khorezm province is regarded as a place where life is harsher and the environment challenges its inhabitants. While Khorezmians take pride in, and are famous for, their local history and culture, rice, and fruits, they must combat the disadvantages of their environment. Scarce precipitation, saline soils, extreme temperatures, the downstream location along the Amu Darya River with impacted river water quality and quantity, and proximity to the Aral Sea disaster characterize the unfavorable situation. The Kyzylkum desert starts $<10 \mathrm{~km}$ from Shurkul, and the population of the villages around Shurkul live in an anthropogenic agricultural environment. Thus, people value places with trees and shade, and the lake landscape is therefore preferred and talked about with pride. For example, one interviewee commented:

When we went to Tashkent, we met some people and we told them that we have a lake here. They were astonished. They said, people pay money to go to such places!

Thus, the lake landscape is considered a site of natural heritage and prestige.

Recreational site

The lake landscape has a special significance in the daily lives of residents, which stands out from other landscapes. Typically for arid landscapes (Burmil et al. 1999), water is considered an important and attractive visual element. The lake landscape is considered a site of beauty and recreation. One interviewee remarked, "Its view is good. When you are worried, you can go to the lake and look at it and you will feel better". Almost every interviewee of this study had pleasant stories to tell about time spent around the lake. Childhood adventures in dense vegetation surrounding the lake were recalled and fishing was frequently mentioned as a favorite pastime.

Symbol of God's benevolence

As discussed previously, the lake has a function in the local ecological knowledge system, is considered a prestige object to people from other regions, and individuals have memories of their recreational experiences around the lake. These three functions are further integrated in a deeper system of symbolic meaning that is strongly connected to people's religious beliefs. Chamberlain (2008) argues that in Islam the environment is considered as God's creation, handed over to humans by God to be taken care of in the sense of the human as regent who is held accountable by God for the health of the environment. This understanding was also found in the statements of some of the interviewees. For instance, one interviewee attempted to explain the 2008 drought by saying:

\section{Maybe God punishes us because we have not taken care of the ecology. We have expanded the cropland and the Aral Sea has dried out and now God is angry.}

As part of the environment, and more importantly one of the few landscapes that people consider to be natural, the lakes are thus part of God's creation which people have the responsibility to protect and which is part of their symbolic universe in a very existential way. As one interviewee said: "If they close the lake there will be no life. But I don't think this will happen. I can't imagine life without the lake". Having no lake seems unimaginable and would be considered a sign of losing God's benevolence. Some interviewees elaborated further on the symbolic meaning of the lakes and revealed a very existential connection to their religious beliefs:

\section{They say even in Mecca people ask about Shurkul. They ask if there is still water in it. They say that if the lakes dry out, it will be judgment day.}

\section{CONCLUSIONS}

In this study we have used the concept of landscape to analyze ecosystem services and socio-cultural dimensions of the Shurkul landscape in the Khorezm province of Uzbekistan. Using landscape as a loosely defined boundary concept, we approached the analysis from different disciplines using both qualitative and quantitative methods. Positivist and phenomenological perspectives were combined.

Our observations indicate that the lake provides ecosystem services such as wildlife habitat, and support for components of the aquatic food web, fodder, building material, and grazing 
Fig. 3. Ecosystem services and social functions fulfilled by the biophysical and the socially constructed lake landscapes.

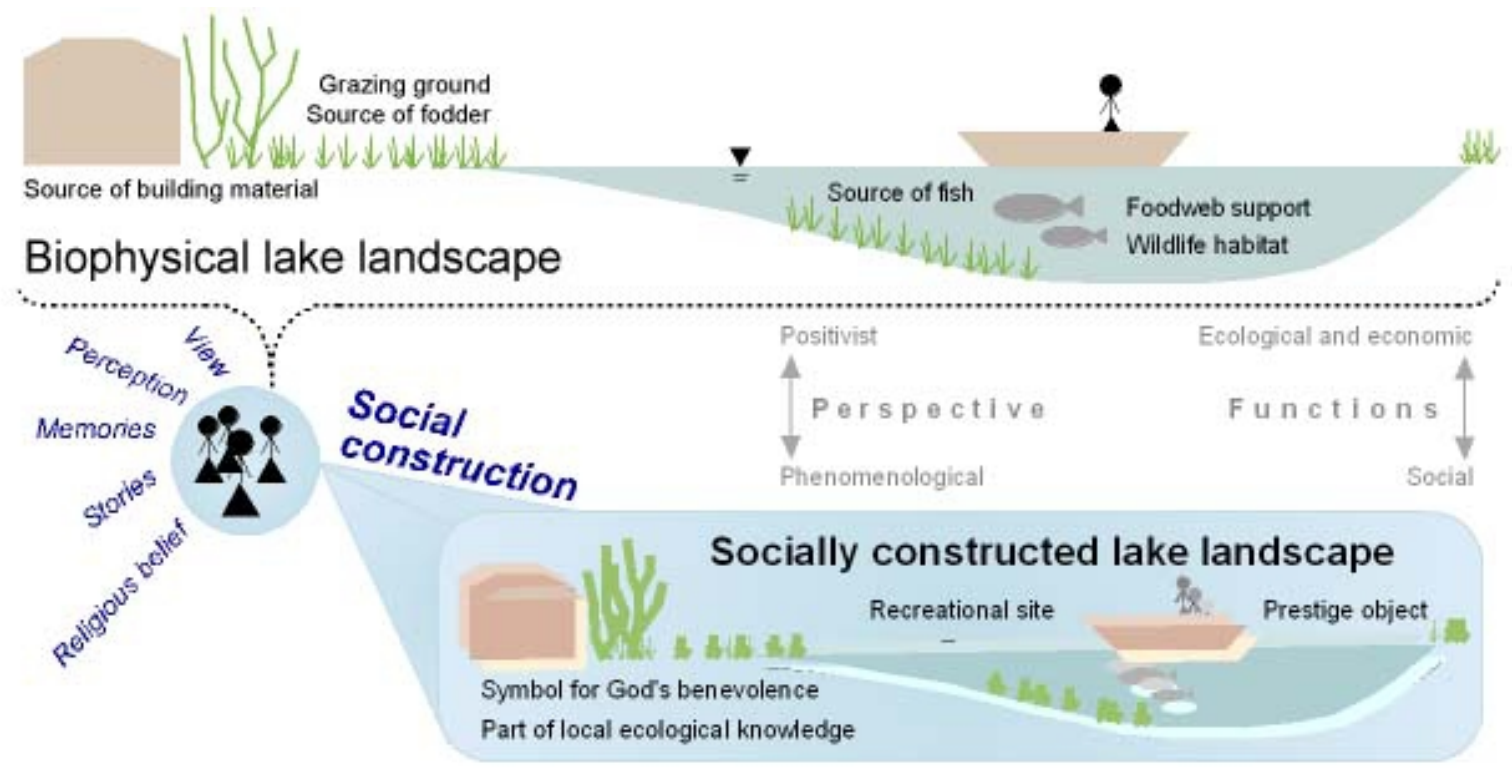

ground. Interviewees of Ortayop and Uyghur are aware of the ecosystem services of the lake and referred to them when stating the importance of the lake. Therefore, it is understandable that people were worried about the state of the lake after the 2008 drought. In addition to the ecosystem service functions, the lake landscape also has a socio-cultural dimension. It is part of local ecological knowledge, functions as a prestige object and recreational site, and is rooted in religious beliefs of the population as a symbol of God's benevolence. Hence, particularly the latter meaning of the lake makes protection of the lake not only a question of rational management of a valuable ecosystem and its services, but a matter of existential importance. Figure 3 summarizes the functions of the lake landscape.

Arid landscapes such as the one in our study are under pressures of increased urbanization and irrigated agriculture all over the world. Central Asia, in particular, is currently facing some of the worst environmental problems in the world, including increasing populations, soil salinization, and increasing water scarcity (Giese and Sehring 2007, Martius et al. 2009, Sehring and Giese 2009). As these environmental problems create the need for all societal groups to manage ecosystems and resources more sustainably, the environmental commitment of decision makers and the local population are essential. In an anthropogenic environment dominated by large fields, canals, and hydraulic structures, the lake landscape of Shurkul was found to be a place where people spend their free time and experience nature as God's creation with its scenic beauty.
While the presented functions of the lake landscape are important to the lives of the local residents per se, the significance of their experiences and beliefs around the lake gains additional relevance with regard to environmental management concerns: in an extremely anthropogenic environment such as the irrigated area of Khorezm, experiencing a lake in the sense of a natural water body as opposed to the network of irrigation canals and drains can be expected to play an important role in the development of a sense of connectedness to nature. Natural and nature are here understood not in the sense of the natural sciences as a meaning- and value-free object of theoretical reasoning, but as an aesthetic perception and an object of value, in terms of use, symbolism, or intrinsically (Trepl et al. 2005). In the field of environmental psychology, connectedness to nature is discussed as one part of nature inclusion, i.e., the extent to which people see themselves as part of nature and not separate from it. Nature inclusion is considered a prerequisite for commitment to environmentally-friendly behavior (Schultz 2002):

Commitment for protecting the environment cannot occur in the absence of caring. Likewise it would seem that caring is unlikely to occur in the absence of connectedness.

When asked in interviews whether the environment should be protected, trees, other vegetation and the lake were the landscape elements mentioned as worth protecting, and environmentally-friendly practices such as water conservation were justified by stating that they are good for the lake. This 
indicates that the local residents connect to the lake landscape and claim ownership of it. A previous study on water use in Khorezm recommended environmental education as a promising and feasible strategy to facilitate water saving in irrigated agriculture (Oberkircher and Hornidge 2011). Including the lake landscape in environmental education programs as an education topic, an outdoor excursion site, and a site for practical conservation activities seems promising for two reasons.

Firstly, environmental management in Central Asia has in the past been driven by the technocratic approach of the Soviet Union of submitting nature to human exploitation. Our findings, however, have shown that despite decades of being exposed to such a discourse, the rural inhabitants acknowledge the value of lakes as natural sites that are intrinsically worth protecting. Strengthening such values and adding a better understanding of ecological causalities could form a counterbalance to the value heritage of the Soviet Union and could facilitate pro-environment behavior in the long term. Secondly, Uzbekistan's agriculture and hence much of the life in the rural areas is under strict state control. Matters of environmental planning and water management are considered the responsibility of the state (O'Hara 2000, Oberkircher and Hornidge 2011) and people have been found to show little agency with regard to bottom-up management approaches (Hornidge et al. 2011). The ownership that people show for Shurkul can thus be considered exceptionally strong and would hence be worth building on in environmental education programs that aim at motivating active proenvironment behavior.

As sites for contact between local populations and nature, landscapes such as the Shurkul landscape may thus create a feeling of environmental connectedness and the desire to act in favor of the natural environment. Particularly in environments under anthropogenic pressure, smaller natural features deserve protection not only for the sake of the ecosystems they host, but also as relevant sites for environmental education.

Responses to this article can be read online at: http://www.ecologyandsociety.org/voll6/iss4/art20/ responses/

\section{Acknowledgments:}

The social science research for this study was conducted under the ZEF/UNESCO Khorezm project "Economic and Ecological Restructuring of Land-and Water Use in the Region Khorezm (Uzbekistan): A Pilot Project in Development Research" funded by the German Federal Ministry of Education and Research (BMBF) (Project Number 339970D). The first author was supported through a grant by the German National Academic Foundation (Studienstiftung des deutschen Volkes). Funding was also provided by the Institute of Landscape Ecology of the Westfälische WilhelmsUniversität Münster (Germany), the North Atlantic Treaty Organization (NATO) Science for Peace Grant 982159 and a student Fulbright Fellowship. The authors would like to thank Prof. Dr. Tillmann Buttschardt, PD Dr. Christopher Martius, Dr. Anna-Katharina Hornidge, Dr. John Lamers, and Dr. Michael Rosen for comments and support.

\section{LITERATURE CITED}

Abdoollaev, F. 2005. Economic analysis of application of a new fish breeding technology in marginal lands. Thesis. Tashkent Institute of Irrigation and Melioration, Tashkent, Uzbekistan.

Berger, P. L., and T. Luckmann. 1966. The social construction of reality: a treatise in the sociology of knowledge. Doubleday, Garden City, New York, USA.

Buchecker, M. 1999. Die Landschaft als Lebensraum der Bewohner. Nachhaltige Landschaftsentwicklung durch Bedürfniserfüllung, Partizipation und Identifikation. Theoretische Begründung, empirische Untersuchung und Evaluation von Methoden zur praktischen Umsetzung. Dissertation. University of Bern, Bern, Switzerland.

Burmil, S., T. C. Daniel, and J. D. Hetherington. 1999. Human values and perceptions of water in arid landscapes. Landscape and Urban Planning 44(2-3):99-109. http://dx.doi.org/10.1016/ S0169-2046(99)00007-9

Chamberlain, G. L. 2008. Troubled waters. Religion, ethics, and the global water crisis. Rowman and Littlefield, Plymouth, UK.

Conrad, C. 2006. Remote sensing based modeling and hydrological measurements to assess the agricultural water use in the Khorezm region (Uzbekistan). Dissertation. University of Wuerzburg, Wuerzburg, Germany.

Conrad, C., S. W. Dech, M. Hafeez, J. Lamers, C. Martius, and G. Strunz. 2007. Mapping and assessing water use in a Central Asian irrigation system by utilizing MODIS remote sensing products. Irrigation and Drainage Systems 21 (3-4):197-218. http://dx.doi.org/10.1007/s10795-007-9029-z

Feld, C. K., P. Martins da Silva, J. P. Sousa, F. deBello, R. Bugter, U. Grandin, D. Hering, S. Lavorel, O. Mountford, I. Pardo, M. Pärtel, J. Römbke, L. Sandin, K. B. Jones, and P. Harrison. 2009. Indicators of biodiversity and ecosystem services: a synthesis across ecosystems and spatial scales. Oikos 118:1862-1871. http://dx.doi.org/10.1111/j.1600-0706 $.2009 .17860 . \mathrm{x}$

Food and Agricultural Organization (FAO). 2009. The state of world fisheries and aquaculture 2008. Fisheries and Aquaculture Department, Rome, Italy. 
Forkutsa, I. 2006. Modeling water and salt dynamics under irrigated cotton with shallow groundwater in the Khorezm region of Uzbekistan. Dissertation. University of Bonn, Bonn, Germany.

Forman, R. T. T. 1981. Interaction among landscape elements: a core of landscape ecology. Pages 35-48 in Proceedings of the International Congress of the Netherlands Society for Landscape Ecology. Pudoc, Wageningen, Netherlands.

Giese, E., and J. Sehring. 2007. Konflikte ums Wasser. Konkurrierende Nutzungsansprüche in Zentralasien. Osteuropa 57(8-9):483-496.

Hard, G., and A. Gliedner. 1977. Wort und Begriff Landschaft anno 1976. Pages 16-24 in F. Achtleitner, editor. Die ware Landschaft: eine kritische Analyse des Landschaftsbegriffs. Residenz Verlag, Salzburg, Austria.

Harrison, P. A., M. Vandewalle, M. T. Sykes, P. M. Berry, R. Bugter, F. deBello, C. K. Feld, U. Grandin, R. Harrington, J. R. Haslett, R. H. G. Jongman, G. W. Luck, P. M. daSilva, M. Moora, J. Settle, J. P. Sousa, and M. Zobel. 2010. Identifying and prioritising services in European terrestrial and freshwater ecosystems. Biodiversity and Conservation 19:2791-2821. http://dx.doi.org/10.1007/s10531-010-9789-x

Hornidge, A.-K., L. Oberkircher, B. Tischbein, G. Schorcht, A. Bhaduri, and A. Manschadi. 2011. Reconceptualizing water management in Khorezm, Uzbekistan. Natural Resources Forum 35(4). http://dx.doi.org/10.1111/j.1477-8947.2011.01391. $\underline{\mathrm{x}}$

Ibrakhimov, M., A. Khamzina, I. Forkutsa, G. Paluasheva, J. P. A. Lamers, B. Tischbein, P. L. G. Vlek, and C. Martius. 2007. Groundwater table and salinity. Spatial and temporal distribution and influence on soil salinization in Khorezm region (Uzbekistan, Aral Sea Basin). Irrigation and Drainage Systems 21(3-4):219-236.

Kamilov, G., and Z. U. Urchinov. 1995. Fish and fisheries in Uzbekistan under the impact of irrigated agriculture. Pages 10-41 in FAO Fisheries Circular No. 894. FAO, Rome, Italy.

Kaiser, B. 2005. The volume of water reservoirs in Khorezm, Uzbekistan. Internal report. ZEF/UNESCO Khorezm Project, Urgench, Uzbekistan and University of Applied Sciences, Nordostniedersachsen, Germany.

Kaufmann, S. 2005. Soziologie der Landschaft. Stadt, Raum und Gesellschaft. VS Verlag für Sozialwissenschaften, Wiesbaden, Germany.

Khadjiyev, T., and A. Bairov. 1992. Fertilizer-nitrogen and nitrification inhibitors in cotton production. FAN, Tashkent, Uzbekistan.
Kienzler, K. M. 2010. Improving the nitrogen use efficiency and crop quality in the Khorezm region, Uzbekistan. Ecology and Development Series 72:265.

Kranz, O. 2005. Development of a land suitability assessment approach for fish pond site selection within the landscape of Khorezm, Uzbekistan, combining geographic information systems and multi-criteria evaluation. Thesis. University of Salzburg, Salzburg, Austria.

Kurambaeva, M. 2008. Improvement of fish feeding technology and development perspectives of aquaculture in Uzbekistan. Dissertation. Academy of Science of Uzbekistan, Tashkent, Uzbekistan.

Löwy, I. 1992. The strength of loose concepts - boundary concepts, federative experimental strategies and disciplinary growth: the case of immunology. History of Science 30 (90):371-396.

Martius, C., J. Froebrich, and E.-A. Nuppenau. 2009. Water resource management for improving environmental security and rural livelihoods in the irrigated Amu Darya Lowlands. Pages 749-762 in H. G. Brauch, U. Oswald Spring, J. Grin, C. Mesjasz, P. Kameri-Mbote, N. Chadha Behera, B. Chourou, and H. Krummenacher, editors. Facing global environmental change: environmental, human, energy, food, health and water security concepts. Hexagon Series on Human and Environmental Security and Peace, Vol. 4. Springer-Verlag, Berlin, Germany; Heidelberg, Germany; New York, USA. http://dx.doi.org/10.1007/978-3-540-68488-6 57

Martius, C., J. P. A. Lamers, P. Wehrheim, A. SchoellerSchletter, R. Eshchanov, A. Tupitsa, A. Khamzina, A. Akramkhanov, and P. L. G. Vlek. 2004. Developing sustainable land and water management for the Aral Sea Basin through an interdisciplinary research. Pages 45-60 in V. Seng, E. Craswell, and S. Fukai, editors. Water in agriculture. ACIAR Proceedings No. 116. Australian Centre for International Agricultural Research (ACIAR), Canberra, Australia.

Micklin, P. 2007. The Aral Sea disaster. Annual Reviews in Earth and Planetary Sciences 36:47-72.

Millenium Ecosystem Assessment. 2005. Ecosystems and human well-being: synthesis, Island, Washington, D.C., USA.

Mollinga, P. P. 2010. Boundary work and the complexity of natural resources management. Crop Science 50:S1-S9.

Nishonov, B., M. R. Rosen, D. Fayzieva, L. Saito, and J. Lamers. 2009. Organochlorine pesticides residue in lakes of Khorezm, Uzbekistan. Pages 157-161 in 10th International HCH and pesticide forum book of papers: how many obsolete pesticides have been disposed of 8 years after signature of Stockholm Convention, 6-10 September, 2009, Brno, Czech 
Republic. International $\mathrm{HCH}$ and Pesticides Association, The Netherlands.

Oberkircher,L. 2011. On pumps and paradigms: water scarcity and technology adoption in Uzbekistan. Society and Natural Resources 24(12):1270-1285. http://dx.doi.org/10.1080/0894 $\underline{1920.2010 .550085}$

Oberkircher, L. and A.-K. Hornidge. 2011. 'Water is life' farmer rationales and water saving in Khorezm, Uzbekistan: a lifeworld analysis. Rural Sociology 76(3):394-421. http://dx .doi.org/10.1111/j.1549-0831.2011.00054.x

O'Hara, S. 2000. Lessons from the past. Water management in Central Asia. Water Policy 2(4-5):365-384.

Olsson, P., and C. Folke. 2001. Local ecological knowledge and institutional dynamics for ecosystem management: a study of Lake Racken watershed, Sweden. Ecosystems 4:85-104. http://dx.doi.org/10.1007/s100210000061

Ostrom, E., and E. Schlager. 1996. The formation of property rights. Pages 127-156 in S. S. Hanna, C. Folke, and K.-G. Maeler, editors. Rights to nature. Ecological, economic, cultural, and political principles of institutions for the environment. Island Press, Washington, D. C., USA.

RoU (Republic of Uzbekistan). 2004a. Law of the Republic of Uzbekistan No. 662-II. On the introduction of amendments and supplements to the Law of the Republic of Uzbekistan "On farming". August 26 $6^{\text {th }}, 2004$.

RoU (Republic of Uzbekistan). 2004b. Resolution of the Cabinet of the Republic of Uzbekistan. About measures on deepening the demonopolization and privatization of the fishery branch. Meeting of the legislation of Republic Uzbekistan. No. 43. 2004.

RoU (Republic of Uzbekistan). 1998. Land Code approved by the Statute of the Republic of Uzbekistan No. 598-I. April 30 $0^{\text {th }}$, 1998. Put into effect by the Resolution of Oliy Majlis No. 599I. April 30 $30^{\text {th }}, 1998$.

Scheer, C., R. Wassmann K. Kienzler, N. Ibragimov, and R. Eschanov. 2008. Nitrous oxide emissions from fertilized, irrigated cotton (Gossypium hirsutum L) in the Aral Sea Basin, Uzbekistan: influence of nitrogen applications and irrigation practices. Soil Biology \& Biochemistry 40:290-301 http://dx. doi.org/10.1016/j.soilbio.2007.08.007

Schultz, W. P. 2002. Inclusion with nature: the psychology of human-nature relations. In P. Schmuck, and W. P. Schultz, editors. Psychology of sustainable development. Kluwer Academic Publishers, Norwell, USA. http://dx.doi.org/10.100 7/978-1-4615-0995-0 4

Scott, J., M. R. Rosen, L. Saito, D. L. Decker. 2011. The influence of irrigation water on the hydrology and lake water budgets of two small arid-climate lakes in Khorezm, Uzbekistan. Journal of Hydrology 410:114-125.

Shanafield, M., M. Rosen, L. Saito, S. Chandra, J. Lamers, and B. Nishonov. 2010. Identification of nitrogen sources to four small lakes in the agricultural region of Khorezm, Uzbekistan, 2006-2008. Biogeochemistry 101:357-368. http:/ /dx.doi.org/10.1007/s10533-010-9509-3

Sehring, J., and E. Giese. 2009. Global environmental change and conflict potential in Central Asia. Pages 525-534 in H. G. Brauch, U. Oswald Spring, C. Mesjasz, J. Grin, P. KameriMbote, B. Chourou, P. Dunay, and J. Birkmann, editors. Coping with global environmental change, disasters and security - threats, challenges, vulnerabilities and risks. HeSeries on Human and EnviSecurity and Peace 5. Springer, Berlin and Heidelberg, Germany. http://dx.doi.org/10.1007/9 78-3-642-17776-7 27

Trepl, L., T. Kirchhoff, and A. Voigt. 2005. Natur. Pages 685-692 in E. -H. Ritter, editor. Handwörterbuch der Raumordnung. Akademie fuer Raumforschung and Landesplanung, Hannover, Germany.

Wecker, B., B. Karimov, B. Kamilov, U. Waller, M. Matthies, and H. Lieth. 2007. Sustainable aquaculture in recirculating systems-feasibility study for the catchment area of the Aral Sea. Institute of Environmental Systems Research, University Osnabrück, Osnabrück, Germany.

Werlen, B. 1986. Thesen zur handlungstheoretischen Neuorientierung sozialgeographischer Forschung. Geographica Helvetica. 41:67-76. 